\section{Evolution of Conservation Tillage Systems for Processing Tomato in California's Central Valley}

\author{
Jeffrey P. Mitchell ${ }^{1}$, Karen M. Klonsky ${ }^{2}$, Eugene M. Miyao ${ }^{3,8}$, \\ Brenna J. Aegerter ${ }^{4}$, Anil Shrestha ${ }^{5}$, Daniel S. Munk ${ }^{6}$, \\ Kurt Hembree ${ }^{6}$, Nicholaus M. Madden ${ }^{7}$, and Thomas A. Turini ${ }^{6}$
}

ADDITIONAL INDEX WORDs. cover crop, no-till, net returns, resource use

Summary. Traditional processing tomato (Solanum lycopersicum) production in California's Central Valley relies heavily on tillage to produce high yields. However, recent research and farm innovation have produced a variety of conservation tillage (CT) management alternatives that cut costs, reduce soil disturbance, and produce fewer emissions. A 12-year study in Five Points, CA, demonstrated that CT methods reduced tractor passes by $40 \%$, lowered tillage costs by $\approx \$ 80$ per acre in 2011 dollars, and achieved comparable yields as standard tillage (ST) methods. As comparable yield performance and net profitability are further demonstrated, an array of CT systems will become increasingly attractive to producers and more common in Central Valley tomato growing areas.

$\mathrm{T}$ he development of the processing tomato industry in California's Central Valley is nothing short of a phenomenal success story that has been built upon numerous innovations and technological advances. Over the past 90 years, CA processing tomato yields per acre have increased over $740 \%$ (Fig. 1). California now accounts for over $95 \%$ of U.S. processing tomato production [California Tomato Growers Association, 2011;

We acknowledge the contributions from farmers Steve Fortner, Fred Leavitt, Alan Sano, and Jesse Sanchez, as well as the field station support of Bert Garza, Jaime Solorio, Merf Solorio, Nelson Vallejo, and Tracy Waltrip in Five Points, CA. Lastly, we acknowledge the fundamental inspiration of the work of Dwayne Beck of the Dakota Lakes Research Farm in Pierre, $\mathrm{SD}$, and the collegial review from University of California Farm Advisor Michelle Leinfelder-Miles.

${ }^{1}$ Department of Plant Sciences, University of California, Davis, One Shields Avenue, Davis, CA 95616

${ }^{2}$ Department of Agricultural and Natural Resource Economics, University of California, Davis, One Shields Avenue, Davis, CA 95616

${ }^{3}$ University of California Cooperative Extension, Yolo County, 70 Cottonwood Street, Woodland, CA 95695

${ }^{4}$ University of California Cooperative Extension, San Joaquin County, 2102 E. Earhart Avenue, Suite 200, Stockton, CA 95206

${ }^{5}$ Department of Plant Science, California State University, Fresno, CA 93740

${ }^{6}$ University of California Cooperative Extension, Fresno County, 1720 S. Maple Avenue, Fresno, CA 93702

${ }^{7}$ Office of International Programs, University of California, Davis, CA 95616

${ }^{8}$ Corresponding author. E-mail: emmiyao@ucdavis.edu.
U.S. Department of Agriculture (USDA), 2012b]. While the productive capacity of the Central Valley rests in large measure upon the region's Mediterranean climate with rain-free summer growing seasons and sustained breeding and genetic improvement efforts (Atherton and Rudich, 1986) that have led to highly adapted varieties, a number of parallel advances in production technology have significantly contributed to this increased productivity.

For example, in the mid-1960s, when the "20-ton per acre yield barrier" was finally broken, the commercial availability of the mechanical harvester coincided with suitable tomato varieties capable of being machine-harvested (Fig. 1). These innovations revolutionized the industry and the proportion of California's tomato acreage planted to machine-harvested tomatoes rose to over $85 \%$ within a few years (Thompson and Blank, 2000). The opening of the California Central Valley Improvement Project in the 1960s brought water through the San Joaquin Valley (SJV) to southern California. This quickly enabled the widespread expansion of surface irrigation of tomatoes throughout the region (California Department of Water Resources, 2012).

By the mid-1980s, when the "30-ton barrier" was broken, another major technology was introduceddrip irrigation for tomato production as a means for improving the uniformity of water application (Table l; Fig. 1). Initially, drip tape was laid on the surface of planting beds and annually retrieved after harvest. By the mid-1990s, however, tape was increasingly being buried 8 to 12 inches below the soil surface. Water shortages, improvements in drip tape technology, and yield gains with this new, highly efficient irrigation method led to the rapid increase in drip irrigation use (Phene, 2010). By the year 2000, an estimated $25 \%$ of the Central Valley's processing tomato acres were irrigated with buried drip systems and current estimates indicate that these systems account for over 85\% of total Central Valley processing tomato acreage. The switch from directseeded to transplanted tomatoes also has been a major technology shift during the past decade.

Tomato production systems that have evolved in California's Central Valley also rely heavily on tillage for seedbed preparation, weed control, and postharvest residue incorporation (Miyao et al., 2008; Stoddard et al., 2007). Intensive tillage and cultivation practices that are used throughout the tomato production season contribute significantly to the crop's yield potential and help producers manage risks such as seedling pests and the need for uniform plant stands.

\begin{tabular}{llll}
\hline $\begin{array}{l}\text { Units } \\
\begin{array}{l}\text { To convert U.S. to SI, } \\
\text { multiply by }\end{array}\end{array}$ & U.S. unit & SI unit & $\begin{array}{l}\text { To convert SI to U.S., } \\
\text { multiply by }\end{array}$ \\
\hline 0.4047 & acre(s) & $\mathrm{ha}$ & 2.4711 \\
0.3048 & $\mathrm{ft}$ & $\mathrm{m}$ & 3.2808 \\
3.7854 & gal & $\mathrm{L}$ & 0.2642 \\
9.3540 & gal/acre & $\mathrm{L} \cdot \mathrm{ha}^{-1}$ & 0.1069 \\
2.54 & inch(es) & $\mathrm{cm}$ & 0.3937 \\
1.1209 & lb/acre & $\mathrm{kg} \cdot \mathrm{ha}^{-1}$ & 0.8922 \\
1 & micron & $\mu \mathrm{m}$ & 1 \\
1.6093 & mile(s) & $\mathrm{km}$ & 0.6214 \\
0.9072 & ton(s) & $\mathrm{Mg}$ & 1.1023 \\
2.2417 & ton/acre & $\mathrm{Mg} \cdot \mathrm{ha}^{-1}$ & 0.4461
\end{tabular}




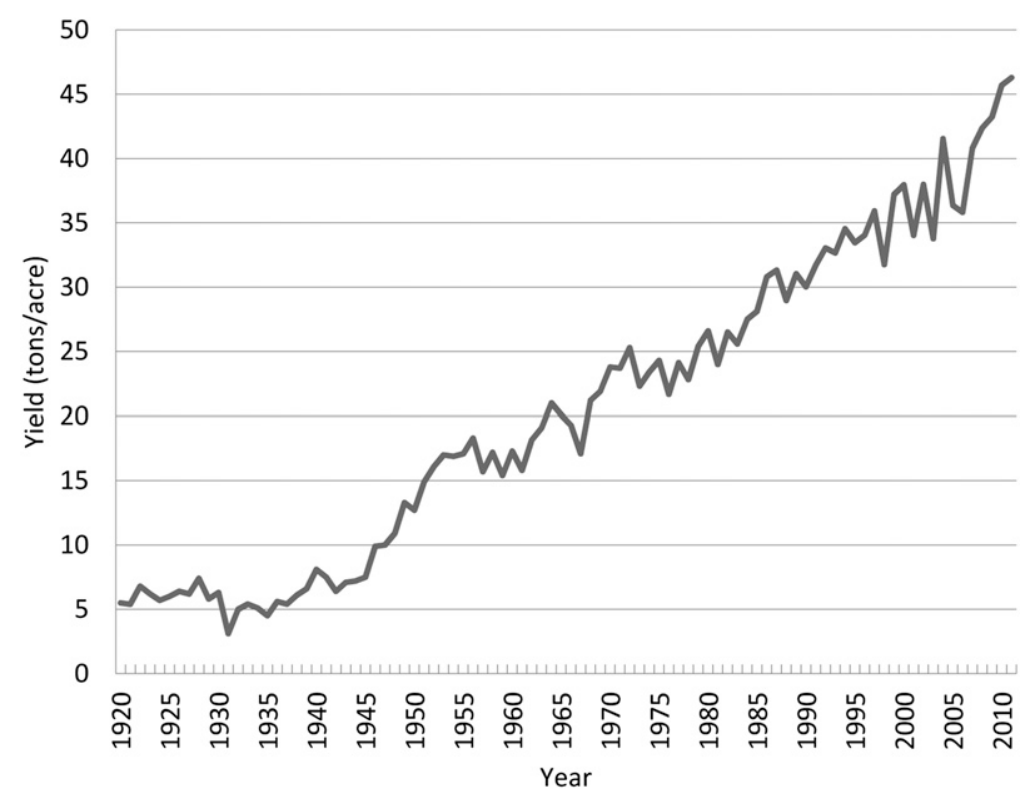

Fig. 1. Processing tomato yield in California, 1920 through 2010 (USDA, 2012a); 1 ton $/$ acre $=2.2417 \mathrm{Mg} \cdot \mathrm{ha}^{-1}$.

Table 1. Estimated adoption of drip irrigation in California's Central Valley processing tomato production from 1980 to 2011 . Data based on an unpublished 2012 survey of over 20 University of California Cooperative Extension Farm Advisors, Central Valley tomato farmers, and consultants.

\begin{tabular}{lc}
\hline Yr & $\begin{array}{c}\text { Acreage under drip } \\
\text { irrigation (\%) }\end{array}$ \\
\hline 1980 & 0 \\
1985 & 1 \\
1990 & 2 \\
1995 & 5 \\
2000 & 25 \\
2005 & 40 \\
2010 & 75 \\
2011 & 85 \\
\hline
\end{tabular}

These tillage and cultivation practices can also be costly (Mitchell et al., 2009; Miyao et al., 2008; Stoddard et al., 2007). Preplant tillage requires not only considerable labor and time but also a number of specialized implements and the corresponding tractor horsepower to pull them. Tillage or soil preparation operations for traditional SJV tomato production systems typically can easily exceed 8 passes (Stoddard et al., 2007) or 10 passes (Miyao et al., 2008) across a field before the crop is planted. While tillage costs historically have not been a major part of overall tomato production budgets (Miyao et al., 2008;
Stoddard et al., 2007), because of rising diesel fuel and equipment costs, they are becoming an increasingly important input expense in recent years.

Despite the recent availability of incentives programs such as the USDA, Natural Resources Conservation Service's Environmental Quality Incentives Program (EQIP) to encourage tillage reduction, as well as the increasing cost of intensive tillage, the majority of SJV tomatoes continue to be produced using traditional, multiple-pass tillage practices largely because these systems are what producers are familiar with and because they have provided reliable productivity in the past (Mitchell et al., 2009; Miyao et al., 2008; University of California, 2012) (Table 2). As a result, tomatoes today are one of the most tillage-intensive annual crops produced in California (Mitchell et al., 2007; University of California, 2012) and ST management systems for SJV tomato production have changed relatively little until quite recently.

During the past decade, however, experience with a number of tillage system alternatives for tomato production in California has increased (Mitchell et al., In press). A variety of "conservation tillage" approaches that reduce the frequency of tillage in tomato production systems have been evaluated and are now beginning to be used by tomato producers. The term "conservation tillage" as defined by the University of California Conservation Agriculture Systems Initiative (Table 3 ) refers to management systems, such as no-till (NT) and striptill, that reduce tillage intensity and soil disturbance to maintain $30 \%$ or more of the soil covered by residues from previous crops after seeding, or that reduce the overall number of tillage passes across a field by $40 \%$ or more relative to what was conventionally done in 2000 (Mitchell et al., 2009). This latter type of CT systems is termed "minimum tillage." Because these "minimum till" approaches reduce the total number of tillage operations, diesel fuel usage is also reduced (Upadhyaya et al., 2001). Dust generation reduction of between $60 \%$ and $80 \%$ has been demonstrated (Baker et al., 2005; Madden et al., 2008). An average fuel saving of $50 \%$ and a timesaving of $72 \%$ have been reported with one-pass tillage equipment (Incorpramaster; New World Tillage, Modesto, CA) compared with the ST program of disking and landplaning in the Sacramento Valley (Upadhyaya et al., 2001). Additionally, recent investigations using advanced atmospheric light detection and ranging measurement techniques conducted in Los Banos, CA, showed the combinedoperations minimum tillage method reduced 2.5-micron particulate matter emissions by $29 \%, 10$-micron particulate matter by $60 \%$, and time and fuel per acre by $40 \%$ and $50 \%$, respectively, compared with conventional methods (J. Hatfield, personal communication). For these reasons, these minimum tillage practices can be justified to be a form of CT. These minimum tillage approaches that preserve planting beds are now widely used in conjunction with subsurface drip irrigation tomato production systems throughout the SJV's West Side region (Mitchell, 2011). However, these alternatives still result in relatively high amounts of soil disturbance and generally do not preserve residues on the soil surface. In this article, we summarize recent research and technological developments related to CT tomato production in California. We start with advances in minimum tillage practices along with farmer innovations in strip-tillage tomato production and then describe recent research findings on NT tomato systems. 
Table 2. Processing tomato acreage in California's Central Valley under different tillage management systems in 2010. Data based on biennial survey conducted by the University of California's Conservation Agriculture Systems Initiative (University of California, 2012).

\begin{tabular}{lcrr}
\hline & $\begin{array}{c}\text { Conservation } \\
\text { tillage }\end{array}$ & $\begin{array}{c}\text { Minimum } \\
\text { tillage }\end{array}$ & $\begin{array}{r}\text { Standard } \\
\text { tillage }\end{array}$ \\
\hline $\begin{array}{l}\text { Area }(\text { acres })^{\mathrm{z}} \\
\begin{array}{l}\text { Proportion of total } \\
\text { acreage }(\%)\end{array}\end{array}$ & 11,325 & 150,287 & 96,216 \\
${ }^{2} 1$ acre $=0.4047$ ha. & 4 & 58 & 37 \\
\end{tabular}

Table 3. Glossary of tillage terminology. To clarify and standardize tillage system nomenclature for California production systems, the Conservation Agriculture Systems Institute has outlined the following general categories of tillage systems. More complete definitions may be found in Mitchell et al. (2009).

Standard tillage

Standard tillage is the sequence of operations most commonly or historically used in a given field to prepare a seedbed and produce a given crop.

Minimum tillage

Adopted by the Conservation Tillage Workgroup as a subcategory of conservation tillage, minimum tillage refers to systems that reduce tillage passes (and thereby conserve fuel use for a given crop) by at least $40 \%$ relative to what was conventionally done in year 2000 .

No-tillage

With no-tillage, the soil remains undisturbed from harvest to planting except for injection of fertilizers. At least $30 \%$ of the soil surface should be covered by residue after planting.

Strip-tillage

With strip-tillage, the seed line is tilled before planting to clear surface plant debris to enhance soil warming and facilitate planting ease, to aerate for soil moisture management, and in some cases may include subsoiling. Typically less than one-third of the soil surface is disturbed, with a target of at least $30 \%$ of the soil surface covered by residue after planting.

Conservation tillage

Conservation tillage has been described as a "collective umbrella term" that denotes practices that have a conservation goal of some nature. The term "conservation tillage" broadly encompasses tillage practices that reduce the volume of soil disturbed, preserve rather than incorporate surface residues, and result in the broad protection of resources while crops are grown. California's Conservation Agricultural Systems Institute defines conservation tillage as including the "classic" surface residue conserving forms of CT (e.g., no-till or strip-till) and minimum tillage systems that reduce tillage passes by $40 \%$ or more.

\section{Evolution of minimum tillage tomato production systems}

Up until $\approx 10$ years ago, SJV tomato production virtually always involved a series of preplant tillage operations that commonly included disking, subsoiling, landplaning, bed formation, and "dry mulching," or shallow cultivation using rolling harrow or various power incorporation implements to kill weeds and to even
While the normal sequence of tillage operations followed in conventional tillage systems is by no means capricious, in many respects tillage in these systems begets tillage (i.e., one tillage operation requires a carefully devised series of follow-up operations). Before tomato seeding or transplanting, residues from previous crops are incorporated, subsoil compacted zones are loosened or fractured, weeds are eliminated, soil clods are broken up, and uniform planting beds are prepared by the coordinated sequence of these tillage operations.

During the past half century, the vast majority of SJV tomato producers have followed a close variant of these common tillage practices. However, this does not mean that there were no innovations in tomato tillage research, equipment, or management during this time. With the development and refinement of subsurface drip irrigation systems for processing tomatoes in the early 1990s, deep tillage near the drip tape was eliminated. Commercial and farmer-developed tillage implements were adopted for bed-preserving, minimum tillage management systems. At the same time, transplants began to be used in lieu of direct seeding for processing tomatoes. The interest in transplanting was initially to establish a more uniform stand, and later the advantages broadened to include a reduction in hand weeding expense, less irrigation, and management during stand establishment and lower seeding rates as seed cost increased. In 1989, transplants were used on just $1 \%$ of processing tomato acreage. By 2000, use was $30 \%$, and by 2011 it was the dominant practice with $90 \%$ of the acreage. The conversion to stand establishment with transplants instead of direct field seeding reduced the need for intensive tillage measures to produce a fine seedbed. Stands established with buried drip irrigation fit better with transplants since moving water to the surface to germinate shallowly planted tomato seed is difficult.

Recent estimates by the University of California Cooperative Extension indicate these "pass combining" minimum tillage implements are used on $90 \%$ of drip irrigated tomato acreage in the central SJV. All tillage avoids disturbing the semipermanent drip tape buried 8 inches or more 
below the surface (Phene, 2010). In particular, conventional deep tillage that included a broadcast stubble disk and a subsoil ripper with 30 -inch-long shanks has been largely eliminated with these "bed-preserving," minimum tillage approaches. As a result, the overall use of reduced tillage in tomato production fields has significantly increased in recent years. Minimum tillage equipment such as the Optimizer (New World Tillage), the Eliminator and the Performer (Wilcox Agriproducts, Walnut Grove, CA), the Hahn Perma Bed Disk (Hahn Tractor, Stockton, CA), and the Sundance Wide Bed Disk (Arizona Drip Systems, Coolidge, AZ) combine tillage tools onto a single frame and therefore serve to combine or reduce passes across a field and also reduce the amount of deep tillage that is done (Mitchell et al., 2009). Adoption rates of various tillage management systems have been surveyed for a number of crops including tomatoes every two years since 2004 . Estimates of tillage systems used in 2010 indicate that minimum tillage is now used on upwards of $56 \%$ of tomato acreage in the Central Valley (Table 2) (Mitchell, 2011).

Two general types of minimum tillage equipment have been introduced since the early 1990s. "Permanent or semipermanent bed" minimum tillage implements such as the Sundance and the Hahn bed disks, and the Wilcox Performer are generally used with global position satellite-guidance steering systems to preserve planting beds and traffic furrows in true "zone tillage," a term originally coined in 1985 (Carter 1985, 1991; Carter et al., 1987). Variations of commercially available permanent bed minimum tillage equipment have also been introduced during the past decade. One example is the one-pass tillage implement developed in 2001 by Jim Couto, a farmer in Kerman, CA, using a Terratill (Bigham Bros., Lubbock, TX) strip-till tool bar fitted with spider gangs (Lilliston, Bigham Bros.) and a roller to recreate and flatten beds before seeding subsequent crops.

The second type of minimum tillage approach that is typified by the Eliminator or the Optimizer does not preserve dedicated planting beds, but rather broadcast tills a field while mixing and incorporating residues and preparing seedbed tilth in a single pass. With any of the minimum tillage implements, tillage operations are combined, fewer passes across a field are required and less deep or vertical tillage is generally performed. However, the extent of horizontal or shallow surface tillage that is performed is generally similar to conventional tillage systems. Unless farmers couple these types of minimum tillage approaches with controlled traffic farming techniques that essentially restrict tractor and implement load traffic away from crop growth zones in a field, the need to relieve tillageinduced subsoil compaction remains present (Alakukku and Elonen, 1995; Botta et al., 2004; Håkansson 1994, 2005; Trautner and Arvidsson, 2003; Vermeulen and Perdok, 1994), and what has been called the "tillage treadmill," is continued.

\section{Strip-till and NT tomato production in California's SJV-case study}

In an attempt to cut costs and reduce the amount of tillage-induced soil disturbance even further, Sun Pacific (Exeter, CA) fresh market tomato farmers, Steve Fortner and Fred Leavitt, initiated the first farm evaluation of strip-till cover cropped fresh market tomato production in California in 2003. In their early efforts, various power-driven as well as ground-driven strip-tillers were used to shallowly incorporate herbicide-terminated barley (Hordeum vulgare) and triticale (Triticale hexaploide) cover crops in the centers of 60 -inch beds before transplanting. Their system was predicated by the use of subsurface drip irrigation (Phene, 2010). The extent of the grass cover crop residue on the bed surface as well as the general bed condition are not factors with the hand harvesting of the fresh market tomato crop as they can be for processing tomatoes. With some refinements including managing the cover crop so that it does not grow large, they continue to use this system today on much of their acreage.

During the past seven years, Sano Farms, also in Firebaugh, CA, has also refined a production system for processing tomatoes that uses cover crops, subsurface drip irrigation, and CT practices. Their system saved fuel by reducing the number of tractor operations, cut fertilizer inputs, reduced labor, improved soil condition, reduced overall variation in yield, and increased tomato yields up to $15 \%$ relative to the standard practices that were previously used (J.P. Mitchell, W.R. Horwath, R.J. Southard, N.M. Madden, D.S. Munk, T. Gohlke, and R. Bickel, unpublished data). Sano Farms in many ways typifies the technological transformations from surface to drip irrigation and from direct seeding to transplanting tomatoes that have become widespread throughout the Central Valley. An important component of the integrated tomato production system at this farm is the use of winter-grown triticale cover crop. These cover crops are typically seeded in late October or early November, sprinkler irrigated as part of the farm's "preirrigation" program for the subsequent year's crop, and then ended with herbicide typically in early February before the aboveground growth becomes too difficult to manage. Sano Farms experimented with various seeding rates of triticale from as low as $45 \mathrm{lb} /$ acre, but are currently using $110 \mathrm{lb} /$ acre to achieve desired cover and growth. The cover crop characteristics that this farm now seeks include high amounts of root biomass, rapid surface cover, and quick breakdown following herbicide application to allow ease of transplanting. They use a 27.5-ft-wide grain drill (Great Plains Manufacturing, Salina, KS) that has been modified to plant only the bed top and not the furrow.

Sano tomato harvesters include on-board shredders to chop vines into small pieces to facilitate the reduced tillage program. Typically, their fall tillage following the tomato harvest consists of three tillage passes. The first of these operations involves a furrowchiseling pass to break compacted zones. The second tillage pass is with a conventional disk pulled in line with the beds. The third pass employs a Performer bed conditioning implement that is used to shallowly mix residues, loosen the soil in the bed, and reshape planting beds for the subsequent season. These tillage passes rely on global position satellite guidance to preserve essentially undisturbed crop growth zones in the centers of beds where long-term buried drip tape lies, and thus perform "zone tillage" on permanent tomato planting beds.

The winter small grain cover crop at Sano Farms is typically ended 
in early February with herbicide before it grows more than about 12 inches tall. The cover crop provides winter weed suppression. The Sano owners believe that their cover crop combined with the overall CT approach results in lower weed populations in the tomato season. However, in recent years, field bindweed (Convolvulus arvensis) growth in-season has become a serious problem requiring additional herbicide control measures in the fall.

Ahead of transplanting processing tomatoes in the spring, this farm uses a ground-driven 1-tRIPr strip-till implement (Orthman Manufacturing, Lexington, NE) to loosen the soil, mix in cover crop residues, and incorporate herbicide into the soil in the center of beds where transplants will be established. This strip-till operation works the soil to a depth of about 8 inches and then leaves a firmed zone of soil into which the transplants will be placed. Starter fertilizer is also applied with the strip-tiller ahead of transplanting. In prior years, Sano Farms used a power take off (PTO)-rototiller mulcher to accomplish this strip-tillage function, but they now use row units of the l-tRIPr. The ground-driven implement can be operated faster and with less maintenance, thus replacing the slower, PTO-driven tillers. A tractor-drawn roller is used to firm the bed after the strip tiller and ahead of transplanting. Sano Farms uses conventional five-row transplanters. Their transplanters require no CT modifications and perform well in the minimal surface cover crop residue that is typically present at the time of transplanting following the strip tiller.

The integrated production techniques that are now successfully used at Sano Farms have been developed through considerable planning as well as very rigorous and detailed trial and error investigations. Management now emphasizes the entire "system" and not merely a sequential combining of different practices. They have found, for example, benefits from their cover crops being left in place on the bed tops as mulch and not being incorporated as green manure. They witnessed better weed control during the winter and summer (except for field bindweed) as well as better overall soil tilth. Improvements in soil quality, such as greater friability are now observed in those fields using this system for a number of years (A. Sano, personal communication). Through years of innovating, adjusting, and refining their system, the Sano Farms goal was to create an entire cropping system that is both profitable year-to-year and also sustainable and self-improving over the long haul.

While changes in soil carbon have not been monitored at Sano Farms, based on recent long-term research with CT and cover crops at the University of California West Side Research and Extension Center (WSREC) in Five Points, CA $(\approx 50$ miles from Sano Farms), it is reasonable to expect that soil carbon levels have increased because of the cover crop inputs at Sano Farms (J.P. Mitchell, W.R. Horwath, R.J. Southard, N.M. Madden, D.S. Munk, T. Gohlke, and R. Bickel, unpublished data).

\section{Long-term CT tomato performance-research study}

One of the earliest records of other forms of CT such as NT and strip-till research in California was work conducted in 1997 by Herrero et al. (2001). This study demonstrated the feasibility of NT furrow-irrigated tomato production under residue mulches, but it did not find adequate season-long weed suppression by the cover crop mulches (without herbicide) compared with a conventional fallow, soil-incorporated herbicide system. In a follow-up study conducted in Meridian, CA, Madden et al. (2004) compared strip-tillage in four cover crop mixtures in organic processing tomato production. Tillage treatments included incorporating the cover crops as green manures and using the cover crops as surface mulches in a NT system. Yields were similar between conventional and NT, but lower with the NT grass-legume mulch system because of competition from regrowth of the grass within the tomato season.

To determine the longer-term impacts of CT tomato systems on productivity, profitability, and soil properties, a study at WSREC has been underway since 2000 in a Panoche clay loam soil (fine-loamy, mixed, superactive, thermic Typic Haplocambids) (Arroues, 2006) comparing ST and CT systems for a cotton (Gossypium hirsutum)/tomato rotation with a rainfed winter cover crop (CC) and without a cover crop (NO). In each year of the study, tomatoes were transplanted directly into beds that were not disturbed following cotton harvest other than with the Sundance Root Puller (Arizona Drip Systems) to dislodge cotton rots as required under the California Department of Food and Agriculture's Pink Bollworm Program to manage pink bollworm (Pectinophora gossypiella). All tractor and implement traffic was restricted to the furrows and planting beds were not moved or tilled, except for shallow weed cultivations during each tomato season. While the exact operations used varied somewhat from year to year, the number of tractor trips across the field was reduced by $\approx 40 \%$ for both tomato and cotton in the CT relative to the ST systems (Table 4).

The field was divided into two halves; a tomato-cotton rotation was used in one half, and a cotton-tomato rotation was pursued in the other half to allow both tomato and cotton plantings and experiments to occur within each year. The management treatments, ST with no cover crop (STNO), ST with cover crop (STCC), CT with no cover crop (CTNO), and CT with cover crop (CTCC) were replicated four times in a randomized complete block design on each half of the field with treatment plot locations fixed over the life of the experiment. Treatment plots consisted of six beds, each measuring $30 \times 300 \mathrm{ft}$. Six-bed buffer areas separated tillage treatments to enable the different tractor operations that were used in each system. A cover crop mix of 'Juan' triticale, 'Merced' cereal rye (Secale cereale), and common vetch (Vicia sativa) was planted at a rate of $80 \mathrm{lb} /$ acre (30\% triticale, $30 \%$ cereal rye, and $40 \%$ common vetch by weight) in late October in the STCC and CTCC plots. In the initial year, irrigation was used to germinate the cover crop. In each of the subsequent years, no irrigation was applied to the cover crops, which were planted in advance of winter rains. The cover crops were chopped in mid-March of the following years using a Buffalo Rolling Stalk Chopper (Bison Industries, Norfolk, $\mathrm{NE}$ ). In the STCC system, the chopped cover crop was disked into the soil to a depth of about 7 inches and 5 - $\mathrm{ft}-$ wide beds were reformed before tomato transplanting. The chopped cover crop in the CTCC system was 
Table 4. The cultural operations under standard tillage (ST) and conservation tillage (CT) system with and without cover crops for processing tomato from 2000 to 2011 at the University of California West Side Research and Education Center in Five Points, CA.

\begin{tabular}{|c|c|c|c|c|}
\hline \multirow[b]{3}{*}{ Operation } & \multicolumn{2}{|c|}{ With cover crop } & \multicolumn{2}{|c|}{ Without cover crop } \\
\hline & ST & CT & ST & CT \\
\hline & \multicolumn{4}{|c|}{ (no. trips over field per crop yr) } \\
\hline Shred cotton & 1 & 1 & 1 & 1 \\
\hline Undercut cotton & 1 & 1 & 1 & 1 \\
\hline Disk & 4 & & 2 & \\
\hline Chisel & 1 & & 1 & \\
\hline Level (triplane) & 1 & & 1 & \\
\hline List beds & 2 & & 1 & \\
\hline Plant cover crop & 1 & 1 & & \\
\hline Spray cover crop & 1 & 1 & & \\
\hline Chop cover crop & 1 & 1 & & \\
\hline Incorporate herbicide, shape beds & 1 & & 1 & \\
\hline Fertilize & 1 & 1 & 1 & 1 \\
\hline Plant tomatoes & 1 & 1 & 1 & 1 \\
\hline Spray herbicide & 1 & 1 & 1 & 1 \\
\hline Cultivate-high-residue cultivator & 2 & 2 & 2 & 2 \\
\hline Fertilize—sidedress & 1 & 1 & 1 & 1 \\
\hline Spray herbicide & 1 & 1 & 1 & 1 \\
\hline Harvest-custom & 1 & 1 & 1 & 1 \\
\hline Total & 22 & 13 & 16 & 10 \\
\hline
\end{tabular}

sprayed with a $2 \%$ solution of glyphosate after chopping and left on the surface as a mulch. Based on our earlier work (Herrero et al., 2001; Madden et al., 2004), we hypothesized that productivity would be improved in the CC systems.

Conventional intercrop tillage practices that knock down and establish new beds following harvest were used in the ST systems (Table 4). The CT systems were managed from the general principle of trying to reduce primary, intercrop tillage to the greatest extent possible. Zone production practices that restrict tractor traffic to furrows were used in the CT systems and planting beds were not moved or destroyed in these systems during the entire study period. All crops were furrow irrigated with no runoff.

In the tomato-planted half of the field, the varieties planted were $\mathrm{H} 8892$ from 2000 through 2007, H9780 in 2008 and 2009, and AB8058 in 2010 and 2011 . Transplants were placed in a single plant line in the center of beds at a 12 -inch, in-row spacing during the first week of April in each year using a modified three-row commercial transplanter fitted with a large 18-inch coulter ahead of each shoe. Treatments received the same fertilizer applications with dry fertilizer (11N-22.7P-0K) applied preplant at
$80 \mathrm{lb} /$ acre using a standard straight fertilizer shank at $\approx 6$ inches below the transplants. Additional N (urea) was side dress applied at $100 \mathrm{lb} /$ acre of $\mathrm{N}$ split in two lines about 7 inches from the transplants and about 6 inches deep about 4 weeks after transplanting.

Mixed model analysis of variance was used to evaluate variation in yield over 12 years of the study, with tillage, cover crop, and year factors designated as fixed effects, with block and plot (nested within block) factors designated as random effects. The analysis was generated using the MIXED Procedure of SAS (version 9.2; SAS Institute, Cary, NC). In the overall analysis, all three two-way interactions were significant (tillage $\times$ cover crop, tillage $x$ year, and cover crop $\times$ year); therefore, no conclusions could be drawn about simple main effects (Table 5 ). The tillage $\times$ cover crop interaction was such that in the CT system yields were $8.8 \%$ higher in the absence of a cover crop $(P=$ 0.0005 ), while there was no effect of cover crops in the ST system. In the absence of a cover crop, yields were $12.8 \%$ higher in the CT system compared with ST $(P<0.0001)$; but with cover crops there was no advantage of the CT system.

Because of interaction with the year factor, the data were analyzed by year; in nine out of 12 years, main effects could be tested due an absence of a tillage $\times$ cover crop interaction. CT systems had higher yields than ST systems in four out of nine years where main effects could be compared. Cover crops reduced yield in four out of nine years. The three years with a significant interaction between cover crop and tillage (2001, 2009, and 2011) was due to the same phenomenon mentioned above for the overall analysis. The yield benefit of the CT system over the ST system was realized only in the absence of a cover crop. Higher tomato yields in the NO systems relative to the $\mathrm{CC}$ systems may have resulted from greater difficulties experienced transplanting tomatoes into the higher surface residue conditions of the $\mathrm{CC}$ systems, and particularly, the CTCC system (J.P. Mitchell, W.R. Horwath, R.J. Southard, N.M. Madden, D.S. Munk, T. Gohlke, and R. Bickel, unpublished data). We observed poorer stand establishment and slower early season growth in the CTCC system. This impact of the cover crops on transplanting success would be ameliorated to a great extent by ST, hence the tillage $\times$ cover crop interaction. The cover crop also may have reduced yield because of the immobilization of soil nitrogen in CC systems where the cover crop mix was predominately composed of triticale and rye relative to vetch.

The reduction in tillage operations in CT compared with ST reduced the cost of production in terms of fuel use, machine labor, and equipment ownership costs. Adopting CT without a cover crop resulted in a reduction of $15 \mathrm{gal} / \mathrm{acre}$ of fuel and $1.0 \mathrm{~h} / \mathrm{acre}$ of machine labor (Table 6). This saving corresponds to a reduction in the number of tillage trips from 16 trips for STNO to 10 trips for CTNO (Table $4)$. With a cover crop, switching from STCC to CTCC reduced the resource use differential further than without a cover crop as the number of operations went from 22 for STCC to 13 for CTCC. The reduction was $20 \mathrm{gal} / \mathrm{acre}$ of fuel and $1.4 \mathrm{~h} /$ acre of machine operator labor (Table 6). The equipment complement also differed between the systems.

The economic value of these resource savings would vary with changes in fuel prices, labor rates, equipment prices, and interest rates used to calculate the annual cost of equipment 


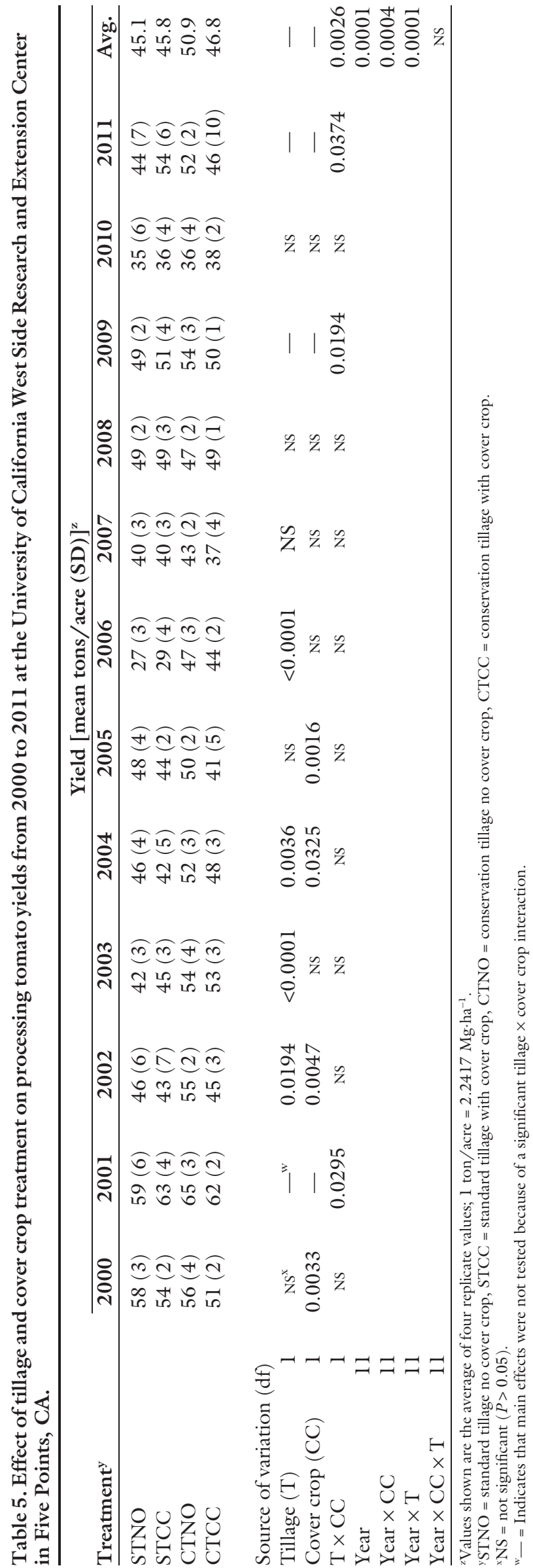

ownership. Under the assumptions of on-farm diesel at $\$ 2.60 / \mathrm{gal}$, labor at $\$ 15.55$ per hour, a mix of new and used equipment, and an interest rate on long-term investments of $7.25 \%$, the least expensive system is CTNO with a savings of $\$ 49$ /acre compared with STNO, followed by CTCC with a savings of $\$ 28$. The cover crop increased operating expenses (fuel, labor, seed, and equipment ownership) by $\$ 74$ /acre for ST and $\$ 46 /$ acre for CT (Table 7). The cost of the cover crop was higher for ST than CT because of two additional disking operations and one listing operation in STCC to incorporate the cover crop that did not occur in CTCC (Table 4).

Net revenue above partial costs was calculated by subtracting cultural costs, harvest costs, and equipment ownership costs from the gross revenue for each system. Equipment ownership does not include harvest equipment as custom harvest by an independent contractor at the cost of $\$ 10.50 /$ ton was assumed. Costs such as land, irrigation system, buildings, taxes, and insurance are assumed to be identical for all systems but variable across farms and therefore are not included in the analysis. Using the average yields from 2007-11 and the average price of $\$ 69.20 /$ ton over the same time period, STNO was the lowest performing system with the lowest revenue and highest costs. CTNO was the highest performing system with the lowest costs and highest revenues, with net revenue above partial costs \$257/ acre higher than STNO. The economic performance of CTCC was very similar to the net returns of STCC that was $\$ 80$ /acre above STNO, and CTCC was $\$ 70 /$ acre above STNO. STCC achieved the increase in net returns by increasing yields despite the increased cost attributable to the cover crop. By contrast, CTCC showed a more modest increase in yield over STNO but a lower cost (Tables 5 and 7).

The long-term nature of this tillage system comparison is unique in CA and has afforded opportunities to evaluate impacts of tillage and cover cropping not only related to production economics but also on a number of additional cropping system attributes (Table 6). The soil conditioning index (SCI) has been proposed by USDA, NRCS as a predictor of the consequences of management on soil organic matter. The 
SCI estimates trends in soil organic matter, which are assumed to be an indicator of soil quality. The NRCS currently uses the SCI as one of its criteria for determining eligibility for Farm Bill conservation programs such as EQIP. The computed SCI values in Table 6 seem to be closely associated with the field operations that were used in the tillage and cover crop systems. SCI values were negative for the two ST systems and positive for the CT systems. Positive SCI values generally indicate that soil carbon is increasing, while negative values suggest degrading trends (USDA, 2003; Zobeck et al., 2007). SCI values that were calculated provide an important case study for evaluating the SCI assessment tool in an irrigated agroecosystem and unique long-term assessment of tillage management impacts on soil quality. Zobeck et al. (2007) have suggested using a buffer of plus or minus 0.2 to 0.3 when reporting SCI values to account for variation suggested in standard errors associated with SCI estimates. The differences in SCI between the ST and CT systems in our work are greater than these "buffered" SCI values, suggesting significant differences in soil resource quality because of management. The soil tillage intensity rating (STIR) is a numerical value that is calculated based on the operational speed of tillage equipment, the particular type of tillage used, the depth of tillage, and the percentage of the soil surface area disturbed to assess the impact of tillage operations on soil quality and residue retention (USDA, 2008). It can also be used as a scoring index for Farm Bill conservation program participation and cost-share eligibility. NT, by definition, requires a STIR value of 30 or less. Values in the national database typically range from 0 to 200 , with a low score preferred. The STIR values presented in Table 6 are, we believe, the first determinations using this assessment tool for SJV tillage systems. Values for both ST systems, and particularly the STCC

Table 6. Effect of tillage and cover crop treatment on soil conditioning index, soil tillage intensity rating, diesel fuel use, and machine labor at the University of California West Side Research and Extension Center in Five Points, CA (Mitchell et al., In press). Values shown are the annual average from 2007 to 2011.

\begin{tabular}{lcccc}
\hline $\begin{array}{l}\text { Cropping } \\
\text { system }^{\mathrm{z}}\end{array}$ & $\begin{array}{c}\text { Soil conditioning } \\
\text { index }^{\mathrm{y}}\end{array}$ & $\begin{array}{c}\text { Soil tillage intensity } \\
\text { rating }^{\mathbf{x}}\end{array}$ & $\begin{array}{c}\text { Diesel fuel } \\
\text { (gal/acre) }^{\mathbf{w}}\end{array}$ & $\begin{array}{c}\text { Machine labor } \\
(\mathbf{h} / \text { acre })^{\mathbf{w}}\end{array}$ \\
\hline STNO & -0.71 & 261 & 24 & 2.4 \\
STCC & -0.96 & 390 & 31 & 3.1 \\
CTNO & 0.43 & 30.6 & 9 & 1.4 \\
CTCC & 0.52 & 37.1 & 11 & 1.7
\end{tabular}

${ }^{\mathrm{z}} \mathrm{STNO}=$ standard tillage no cover crop, $\mathrm{STCC}=$ standard tillage with cover crop, CTNO = conservation tillage no cover crop, CTCC = conservation tillage with cover crop.

"Positive soil conditioning index values generally indicate that soil carbon is increasing, while negative values suggest degrading trends (USDA, 2003; Zobeck et al., 2007).

${ }^{x}$ The soil tillage intensity rating is calculated based on the operational speed of tillage equipment, the particular type of tillage used, the depth of tillage, and the percent of the soil surface area disturbed to assess the impact of tillage operations on soil quality and residue retention. Values typically range from 0 to 200 , with a low score preferred.

${ }^{\mathrm{w}} \mathrm{l} \mathrm{gal} / \mathrm{acre}=9.3540 \mathrm{~L} \cdot \mathrm{ha}^{-1}, \mathrm{l} \mathrm{h} /$ acre $=2.471 \mathrm{l} \mathrm{h} \cdot \mathrm{ha}^{-1}$.

Table 7. Effect of tillage and cover crop treatment on revenue, cost of production, and net return above partial costs for processing tomato, University of California West Side Research and Extension Center in Five Points, CA. Values shown are annual averages from 2007 to 2011 .

\begin{tabular}{|c|c|c|c|c|c|c|c|c|c|}
\hline \multirow[b]{2}{*}{ Treatment $^{\mathrm{z}}$} & \multirow[b]{2}{*}{$\begin{array}{l}\text { Revenue } \\
(\$ / \text { acre })^{y}\end{array}$} & \multicolumn{6}{|c|}{ Costs of production ( $\$ /$ acre) } & \multicolumn{2}{|c|}{ Net returns (\$/acre) } \\
\hline & & Fuel & Labor & $\begin{array}{l}\text { Other cultural } \\
\text { costs }^{\mathrm{x}}\end{array}$ & $\begin{array}{l}\text { Equipment } \\
\text { ownership }\end{array}$ & $\begin{array}{c}\text { Total of } \\
\text { partial costs }\end{array}$ & Harv-est $^{\mathrm{w}}$ & $\begin{array}{c}\text { Above partial } \\
\text { costs }^{v}\end{array}$ & $\begin{array}{c}\text { Compared } \\
\text { to STNO } \\
\end{array}$ \\
\hline STNO & 3,003 & 62 & 38 & 800 & 40 & 940 & 456 & 1607 & - \\
\hline STCC & 3,183 & 80 & 49 & 830 & 55 & 1014 & 483 & 1687 & 80 \\
\hline CTNO & 3,211 & 23 & 21 & 800 & 15 & 859 & 487 & 1864 & 257 \\
\hline CTCC & 3,045 & 29 & 26 & 830 & 20 & 905 & 462 & 1677 & 70 \\
\hline
\end{tabular}

${ }^{z} \mathrm{STNO}=$ standard tillage no cover crop, $\mathrm{STCC}=$ standard tillage with cover crop, CTNO = conservation tillage no cover crop, $\mathrm{CTCC}=\mathrm{conservation}$ tillage with cover crop. y $\$ 1 /$ acre $=\$ 2.4711 /$ ha.

Other cultural costs include tomato seed, cover crop seed, water, pest control materials, and fertilizer.

${ }^{w}$ Custom harvest cost is assumed at $\$ 10.50 /$ ton $(\$ 11.574 / \mathrm{Mg})$.

${ }^{v}$ Net returns above partial costs calculated as gross income minus fuel, labor, cover crop seed, other cultural costs, and harvest costs. Costs do not include land, irrigation system, management, property taxes, property insurance, or building costs. 
Electronic color sorters then remove dirt clods and green fruit leaving red fruit that are eventually transported into trailers for delivery to processing facilities. Air suction on the harvesters typically removes the majority of lighter fraction debris. However, there is an increased likelihood of more debris (a truck-load, reject category by mandatory inspection standards) reaching hand sorting crews on the harvesters and inevitably reaching the processing facility. The extent to which clean, residue-free loads of product can be harvested and delivered to processing plants will be a critical determinant of whether high-residue CT systems further expand in SJV tomato production systems. This is not an issue for fresh market tomato production since harvesting is exclusively by hand.

The second possible constraint to sustained CT management in tomatocontaining rotations is soil compaction. To date, no rigorous determinations of possible subsurface compacted zones arising from tractor and implement traffic have been conducted in any of the recent CT evaluations that have taken place in the SJV. The bulk of the work reported here has either been of short duration, used minimum till equipment that has been successful in alleviating compaction, or relied on dedicated traffic and crop growth zone production approaches that themselves minimize compaction risks. To be sustainable over the long term, CT systems will likely need to employ some combination of very deliberate compaction avoidance with perhaps targeted zone or vertical tillage (Carter, 1996).

For example, bed compaction could be confined to the furrow with the modification from dual to singletired axles on bulk trailers that haul tomatoes directly from the field to the cannery. Tractors in the field that pull the trailers could avoid using dual rear tires by upgrading to include fourwheel drive for the necessary traction.

The cost savings and general resource conservation benefits that may be gained by CT tomato production systems, and that have recently been demonstrated in a number of the studies reported here, thus warrant further evaluation and development. Provided yield performance, or more importantly, bottom-line profitability is maintained, the CT systems or appropriate modifications of them will be increasingly attractive to producers and more common in SJV tomato growing areas.

\section{Literature cited}

Alakukku, L. and P. Elonen. 1995. Longterm effects of a single compaction by heavy field traffic on yield and nitrogen uptake of annual crops. Soil Tillage Res. 36:141-152.

Arroues, K.D. 2006. Soil survey of Fresno County, California, western part. 29 June 2012. <http://soildatamart.nrcs.usda gov/Manuscripts/CA653/0/fresno.pdf>.

Atherton, J.G. and J. Rudich (eds.). 1986. The tomato crop: A scientific basis for improvement. Chapman \& Hall, London.

Baker, J.B., R.J. Southard, and J.P. Mitchell. 2005. Agricultural dust production and composition in standard and conservation tillage systems in the San Joaquin Valley. J. Environ. Qual. 34:1260-1269.

Botta, G.F., D. Jorajuria, R. Balbuena, and H. Rosatto. 2004. Mechanical and cropping behaviour of direct drilled soil under different traffic intensities: Effect on soybean (Glycine max L.) yields. Soil Tillage Res. 78:53-58.

California Department of Water Resources. 2012. History of the California state water project. 5 July 2012. <http:// www.water.ca.gov/swp/history.cfm>.

California Tomato Growers Association. 2011. California tomatoes for processing. 26 Aug. 2012. <http://ctga.org/statistics>.

Carter, L.M. 1985. Wheel traffic is costly. Trans. Amer. Soc. Agr. Eng. 28:430-434.

Carter, L.M. 1991. Zone production system for cotton: Soil response. Trans. Amer. Soc. Agr. Eng. 34:354-360.

Carter, L.M. 1996. Tillage, p. 175-186. In: S.J. Hake, T.A. Kerby, and K.D. Hake (eds.). Cotton production manual. Univ. California Div. Agr. Natural Resources Publ. 3352.

Carter, L.M., E.A. Rechel, and B.D. Meek. 1987. Zone production system concept. Acta Hort. 210:25-34.

Håkansson, I. (ed.). 1994. Subsoil compaction by high axle load traffic. Soil Tillage Res. 29:105-306.

Håkansson, I. 2005. Machinery-induced compaction of arable soils-incidence, consequences and countermeasures. Swedish Univ. Agr. Sci., Div. Soil Mgt. Rpt. No. 109.

Herrero, E.V., J.P. Mitchell, W.T. Lanini, S.R. Temple, E.M. Miyao, R.D. Morse, and E. Campiglia. 2001. Use of cover crop mulches in a no-till furrow-irrigated processing tomato production system. HortTechnology 11:43-48.

Madden, N.M., J.P. Mitchell, W.T. Lanini, M.D. Cahn, E.V. Herrero, S. Park, S.R. Temple, and M. Van Horn. 2004. Evaluation of conservation tillage and cover crop systems for organic processing tomato production. HortTechnology 14:243250.

Madden, N.M., R.J. Southard, and J.P. Mitchell. 2008. Conservation tillage reduced PMl0 emissions in dairy forage rotations. Atmos. Environ. 42:37953808 .

Mitchell, J.P. 2011. Tillage practices changing. 8 Aug. 2012. <http://casi.ucanr.edu/ ?blogpost $=6429 \&$ blogasset $=14128>$.

Mitchell, J.P., K.M. Klonsky, A. Shrestha, R. Fry, D. DuSault, J. Beyer, and R. Harben. 2007. Adoption of conservation tillage in California: Current status and future perspectives. Aust. J. Exp. Agr. 47: 1383-1388.

Mitchell, J.P., E.M. Miyao, K.M. Klonsky, and R.L. DeMoura. Cover cropping and conservation tillage in California processing tomato production systems. Univ. California Div. Agr. Natural Resources, Oakland, CA. (In press).

Mitchell, J.P., G.S. Pettygrove, S. Upadhyaya, A. Shrestha, R. Fry, R. Roy, P. Hogan, R. Vargas, and K.J. Hembree. 2009. Classification of conservation tillage practices in California irrigated row crop systems. Univ. California Div. Agr. Natural Resources Publ. 8364.

Miyao, G.M., K.M. Klonsky, and P. Livingston. 2008. Sample costs to produce processing tomatoes transplanted in the Sacramento Valley. 29 June 2012. <http://coststudies.ucdavis.edu/files / tomatoessvl_2008.pdf>.

Phene, C.J. 2010. Drip irrigation can reduce California's water application by $2.4 \times 10^{6} \mathrm{ac}-\mathrm{ft}$. per year without yield reduction. Proc. 5th Natl. Decennial Irr. Conf. p. 1-28.

Stoddard, C.S., M. Le Strange, B.J. Aegerter, K.M. Klonsky, and R.L. DeMoura. 2007. Sample costs to produce fresh market tomatoes. 29 June 2012. <http://coststudies.ucdavis.edu/files / tomatofrmktsj07.pdf>

Thompson, J.P. and S.C. Blank. 2000. Harvest mechanization helps agriculture remain competitive. Calif. Agr. 54(3):51-56.

Trautner, A. and J. Arvidsson. 2003. Subsoil compaction caused by machinery traffic on a Swedish Eutric Cambisol at different soil water contents. Soil Tillage Res. 73:107-118. 


\section{Reviews}

University of California. 2012. Conservation agriculture systems innovation: 2010 Tillage practices survey findings 29 June 2012. <http://casi.ucanr.edu/files/134904. pdfs.

Upadhyaya, S.K., K.P. Lancas, A.G. SantosFilho, and N.S. Raghuwanshi. 2001. One-pass tillage equipment outstrips conventional tillage method. Calif. Agr. 55(5):44-47.

U.S. Department of Agriculture. 2003. Interpreting the soil conditioning index: A tool for measuring soil organic matter trends. Natural Resources Conservation Serv. Soil Quality Inst. Agron. Tech. Note No. 16.
U.S. Department of Agriculture. 2008. Soil tillage intensity rating (STIR). 1 Aug. 2012. <http://www.pa.nrcs.usda.gov/ technical/Fact_Sheets/STIR_May08. $\mathrm{pdf}>$.

U.S. Department of Agriculture. 2012a. California historic commodity data, California processing tomatoes, 1920-2011. 5 July 2012. <http://www.nass.usda.gov/ Statistics_by_State/California/Historical_ Data/Tomatoes-P.pdf>.

U.S. Department of Agriculture. 2012b. Vegetables: 2011 Summary. 5 July 2012. <http://usda0l.library.cornell.edu/ usda/nass/VegeSumm//2010s/2012/ VegeSumm-01-26-2012.pdf>.
Vermeulen, G.D. and U.D. Perdok. 1994. Benefits of low ground pressure tyre equipment, p. 447-478. In: B.D. Soane and C. van Ouwerkerk (eds.). Soil compaction in crop production. Elsevier, Amsterdam, The Netherlands.

Zobeck, T.M., J. Crownover, M. Dollar, R.S. Van Pelt, V. Acosta-Martinez, K.F. Bronson, and D.R. Upchurch. 2007. Investigation of soil conditioning index values for southern high plains agroecosystems. J. Soil Water Conserv. 62(6):433442. 